\title{
KEPUASAN STAKEHOLDER DALAM OLAHRAGA MULTI EVENT SEBAGAI MODAL SPORT MARKETING
}

\author{
Sapto Adi \\ Fakultas Ilmu Keolahragaan \\ Universitas Negeri Malang \\ J1. Semarang 5 Malang, 65145, Indonesia \\ Sapto.adi.fik@um.ac.id
}

\begin{abstract}
Abstrak: Pemasaran dibidang olahraga pada saat ini berkembang begitu pesat di era revolusi industri 4.0. Pemasaran olahraga tidak hanya diterapkan pada produk barang dan jasa, namun juga termasuk hasil kekayaan intelektual keolahragaan. Dalam multievent olahraga diperlukan pengelolaan yang baik dari tahap persiapan, pelaksanaa, dan evaluasi kegiatan. Evaluasi sebagai salah satu cara untuk mengetahui keberhasil kegiatan. Berdasarkan evaluasi kegiatan diperoleh hasil bahwa sebagian besar responden memberikan balikan yang baik dan sangat baik, serta respon yang positif terhadap pelaksanakan kegiatan multievent olahraga. Kepuasan stakeholder ini di masa yang akan datang dapat dipergunakan sebagai modal untuk memasarkan event olahraga kepada custumer.
\end{abstract}

Kata kunci: sport marketing, kepuasan, stakeholder

Pemasaran di bidang olahraga pada saat ini berkembang begitu pesat, terlebih di era revulusi industri 4.0. Pemasaran olahraga tidak hanya diterapkan pada produk barang, jasa semata, namun juga termasuk kekayaan intelektual keolahragaan. Produk pemasaran olahraga saat ini dapat dimaknai tidak sebatas pada barang/benda yang langsung dapat dipergunakan oleh customer, namun juga termasuk barang yang berupa softfile yang dapat di pasarkan di dunia maya. Sebagai contoh hasil pemikiran tentang keolahragaan yaitu konsep tentang program latihan fisik, teknik dan mental dalam suatu bentuk aplikasi yang dapat dijual dengan cara berbayar melalui sistem online.

Demikian juga model pemasaran olahraga saat sekarang tidak dibatasi oleh wilayah tertentu, namun sudah melewati batas-batas wilayah dalam negara maupun antar negara. Hal ini disebabkan oleh kemajuan dan perkembangan teknologi yang demikian pesat yang mampu menghilangkan batas wilayah berdasarkan geografis semata. Perkembangan teknologi ini menyebabkan pemasaran olahraga saat ini begitu cepat yang dapat dilakukan lewat cara-cara online. Dengan kata lain bahwa pemasaran olahraga sudah tidak dibatasi oleh wilayah tertentu dan juga negara tertentu, tetapi sudah merambah keseluruh dunia.

Dengan menggunakan teknologi online system, maka pemasaran olahraga saat ini tidak lagi dibatasi oleh waktu, akan tetapi sepajang waktu berjalan. Kecuali model pemasaran olahraga yang masih bertumpu pada pemasaran yang menggunakan model konvensional. Artinya model pemasaran yang masih memerlukan tempat dan gedung tertentu. Model pemasaran yang menggunakan online system memberikan kemudahkemudahan orang berusaha tanpa dibatasi oleh waktu. Namun yang perlu dipersiapkan dalam model pemasaran ini adalah kesiapan dalam pemanfaatan teknologi yang serba memiliki fitur-fitur digital. 
Persoalan yang dihadapi dalam pemanfaatan model pemasaran olahraga dengan sistem online adalah kesiapan akan kompetensi yang dimiliki pelaku usaha itu dalam menguasai teknologi digital itu secara personal. Disisi lain, pemanfaatan kompetensi orang lain dalam penggunaan teknologi digital juga dapat dilakukan, mengingat saat ini juga cukup banyak ahli-ahli teknologi informasi yang memiliki kemampuan dalam melakukan pemasaran olahraga secara sistem digital. Cara lain yang dapat digunakan selain kedua cara tersebut adalah dengan cara membeli software berbayar yang sudah banyak dijual di dunia maya. Penggunaan cara ini, yang perlu diperhatikan adalah bahwa software yang akan dibeli tersebut hendaknya disesuaikan dengan tingkat kebutuhan dan kesesuaian dengan jenis wirausaha yang akan dilakukan. Hal ini dimaksudkan agar pemanfaatan software berbayar tersebut dapat mencapai tujuan yang diinginkan.

Era revoulusi industri 4.0 ditandai dengan perkembangan teknoogi informasi yang begitu cepat, sehingga hampir kebanyakan perangkat elektronik berbasis fitur-fitur digital. Kemampuan individu menyesuaikan terhadap perubahan yang begitu cepat ini sangat diperlukan sehingga dampak yang begitu masif terhadap segala lini kehidupan masyarakat dapat tereduksi. Dampak tersebut juga berimbas pada industri keolahragaan dan secara khusus pada komponen pemasaran olahraga. Modelmodel pemasaran olahraga yang standar bersifat konvensional sudah harus dirubah, dengan menggunakan sistem online. Penggunaan sistem ini dapat menyebabkan perubahan yang begitu cepat ke arah kemajuan selama dikelola dengan cara profesional.

Cara memasarkan melalui online ini dapat dilakukan dengan beberapa cara, antara lain: (1) pemanfaatan website penjualan yang sudah cukup terkenal dengan cara bergabung sebagai agen penjual sarana olahraga, (2) menciptakan website sendiri sebagai sarana atau wadah untuk melakukan penjualan secara online.

Pertama kita melihat konsep olahraga didefinisikan sebagai kegiatan, pengalaman atau perusahaan bisnis yang berpusat pada atletik, kesehatan dan kebugaran, rekreasi, dan peluang waktu luang. Beberapa kesalahpahaman umum tentang olahraga termasuk yang berikut: (1) perlu ada situasi kompetitif; (2) penawaran harus memiliki seperangkat aturan standar; dan (3) peserta membutuhkan peralatan dan fasilitas khusus. Ini berlaku untuk olahraga, yang hanya mengacu pada kegiatan olahraga individu, ganda dan tim seperti sepak bola, bisbol, golf dan tenis. Olahraga adalah istilah menyeluruh yang mencakup semua aspek yang melampaui bidang permainan, termasuk semua berbagai operasi yang membuat game terjadi

Pemasaran olahraga adalah bidang yang didedikasikan untuk mengiklankan dan menjual produk dan acara yang terkait dengan olahraga. Istilah 'pemasaran' cenderung digunakan dalam berbagai cara. Beberapa orang menganggap pemasaran sebagai penggunaan teknik iklan, publisitas dan penjualan pribadi untuk membuat orang lain sadar akan suatu produk, atau untuk menarik lebih banyak konsumen untuk membelinya. Namun, pemasaran jauh lebih komprehensif daripada interpretasi yang sempit ini. Sederhananya, pemasaran berarti fokus pada memuaskan kebutuhan pelanggan atau konsumen. Pada gilirannya, ini berarti bahwa pemasaran olahraga difokuskan untuk memenuhi kebutuhan pelanggan olahraga atau konsumen, termasuk 
orang-orang yang terlibat dalam olahraga, menonton atau mendengarkan program olahraga, membeli barang dagangan, mengumpulkan memorabilia, membeli barang olahraga seperti pakaian dan sepatu, atau bahkan menjelajahi situs web yang terkait dengan olahraga untuk mengetahui kabar terbaru tentang tim, pemain, atau acara favorit mereka. Istilah 'konsumen' dan 'pelanggan' digunakan di seluruh teks ini. Konsumen olahraga adalah seseorang yang umumnya menggunakan produk atau layanan olahraga. Pelanggan olahraga adalah seseorang yang membayar untuk penggunaan produk atau layanan tertentu (Stewart, B., \& Smith, A. C, 2014).

Pemasaran olahraga menggunakan olahraga, dalam bentuk apa pun, untuk membantu menjual barang dan jasa. Gaya pemasaran khusus ini kurang tentang penggunaan strategi tunggal dan lebih banyak tentang penggunaan konten olahraga untuk membantu upaya pemasaran. Ini tidak terbatas pada olahraga profesional, dan mungkin termasuk atletik perguruan tinggi, liga kecil, atau olahraga alternatif. Pemasaran umumnya digambarkan sebagai proses perencanaan dan pelaksanaan kegiatan yang dirancang untuk memenuhi kebutuhan atau keinginan pelanggan. Pemasaran olahraga adalah aplikasi konsep pemasaran untuk produk dan layanan olahraga, dan pemasaran produk nonolahraga melalui asosiasi olahraga

Karena olahraga dapat ditonton di berbagai platform, pemasaran olahraga dapat mengambil banyak bentuk yang berbeda. Tim menjual ruang iklan di dalam stadion mereka kepada pemasar yang ingin membeli papan iklan dan iklan cetak lainnya, sementara jaringan TV menjual airtime selama acara berlangsung. Atlet terkenal juga menandatangani kontrak untuk bekerja untuk pendukung selebriti dan meminjamkan gambar mereka kepada para pemasar.

Pemasaran olahraga adalah subdivisi pemasaran yang berfokus pada promosi acara olahraga dan tim serta promosi produk dan layanan lain melalui acara olahraga dan tim olahraga. Ini adalah layanan di mana elemen yang dipromosikan dapat berupa produk fisik atau nama merek. Tujuannya adalah menyediakan strategi bagi klien untuk mempromosikan olahraga atau mempromosikan beberapa produk, layanan, bisnis, atau kegiatan lain melalui olahraga. Pemasaran olahraga juga dirancang untuk memenuhi kebutuhan dan keinginan konsumen melalui proses pertukaran. Strategi ini mengikuti empat "P" pemasaran produk, harga, promosi, dan tempat umum. Secara umum: empat "P" lainnya ditambahkan ke pemasaran olahraga, terkait dengan fakta olahraga dianggap sebagai layanan. Tambahan empat "P" adalah: perencanaan, pengemasan, pemosisian, dan persepsi, penambahan empat elemen ekstra di sebut "bauran pemasaran olahraga.

Sport marketing dinilai cukup efektif. Hal tersebut terlihat dari mulai banyaknya merek-merek yang menggunakan cara ini. Di Amerika Serikat dan Eropa, kita bisa melihat betapa mereka berlomba-lomba mensponsori klub-klub sepakbola besar. Hasilnya, jutaan bahkan miliaran dolar digelontorkan untuk itu. Sekarang, sport marketing tidak hanya digunakan oleh merek-merek olahraga saja, beragam merek mulai merasakan manfaat dari sport marketing. Mereka seperti alfamart dan Mcdonald sudah sangat akrab dengan sport marketing. Pemasaran olahraga adalah elemen promosi olahraga yang melibatkan 
berbagai sektor industri olahraga, termasuk penyiaran, iklan, media sosial, platform digital, penjualan tiket, dan hubungan masyarakat.

Dalam melaksanakan kegiatan pemasaran, perusahaan mengkombinasikan empat variabel yang sangat mendukung didalam menentukan strategi pemasaran, kombinasi keempat variabel itu dikenal dengan istilah bauran pemasaran (marketing mix) yang terdiri dari produk (product), harga (price), distribusi (place) dan promosi (promotion). Namun juga meninjau dari segi place, people, process, dan physical evidence yang selanjutnya dikenal dalam istilah bauran pemasaran jasa sebagai $7 \mathrm{P}$.

Berangkat dari beberapa pertimbangan di atas maka peneliti ingin mengumpulkan informasi terkait olahraga multi event. Dari data yang dikumpulkan tersbut nantinya akan dianalisis dan digunakan untuk menentukan langkah untuk mengembangkan Sport Marketing.

\section{METODE}

Rancangan yang digunakan dalam penelitian ini adalah survei dengan menggunakan instrumen google form. Responden penelitian adalah para atlet di cabang olahraga, manager tim, dan juga penonton. Sedangkan jenis-jenis olahraga dalam survei ini antara lain: bola basket, bolavoli, tenis meja, sepakbola, tenis. Proses pengumpulan data dilakukan dengan menggunakan sarana handphone dan melalui media sosial dengan jenis aplikasi whatapps.

\section{HASIL}

\section{A. Respon Staheholder sebagai User dalam Kegiatan Multievent}

Kepuasan pelanggan merupakan salah satu bentuk respon yang dapat dijadikan alat ukur terhadap penyelenggaran sebuah event keolahragaan. Dalam penelitian ini, penulis melakukan survei pada aspek yang masih bersifat parsial dari pemasaran olahraga. Hasil dari survei tentang kepuasan pelanggan meliputi beberapa indikator, sekaligus terhadap atlet, official/koordinator/manajer, dan penonton yang masuk memberikan respon dengan sejumlah 10 orang. Responden berasal dari 8 (delapan) atau $80 \%$ sebagai atlet, 1 (satu) atau $10 \%$ orang sebagai official/koordinator/ manajer, dan 1 (orang) sebagai penonton.

Hasil survei antara lain respon dari para stakeholder berasal dari dari beberapa cabang olahraga, official/koordinator/manajer, dan penonton. Sedangkan yang memberikan respon dari para stakeholder berasal dari cabang olahraga, 1) bola basket 3 (tiga) orang atau (30\%), sepakbola 4 (empat) orang atau 40\%, bolavoli 1 (satu) orang atau (10\%), dan tenis lapangan 2 (dua) orang atau (20\%).

\section{Kelengkapan Sarana Pertandingan}

Kelengkapan sarana yang digunakan dalam pertandingan multievent ini, menurut para responden, sebagai berikut: 1) 2 (dua) orang atau (20\%) menyatakan sangat lengkap, 2) sedangkan 5 (lima) orang atau (50\%) menyatakan lengkap, 3) 2 (dua) orang atau $(20 \%)$ menyatakan cukup lengkap, dan 1 (satu) orang atau (10\%) menyatakan kurang lengkap. Dari hasil respon yang diperoleh dari pertanyan tentang kelengkapan sarana yang digunakan, maka dapat di maknai bahwa sarana yang digunakan dalam penyelenggaraan pertandingan olahraga multievent dalam kategori $90 \%$ lengkap. 


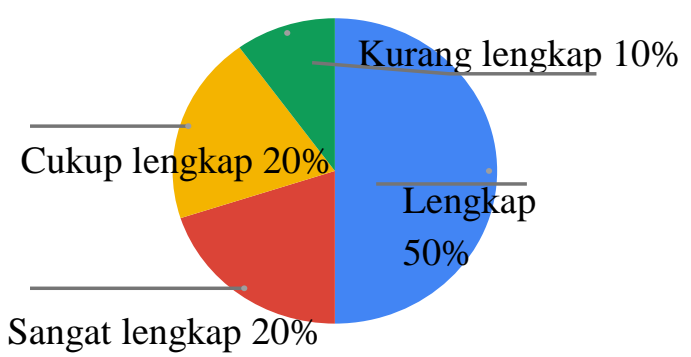

\section{Kualitas Sarana Pertandingan}

Berdasarkan respon yang diperoleh berkenaan dengan kualitas sarana yang digunakan, maka menunjukkan hasil sebagai berikut: (1) 4 (empat) orang $(40 \%)$ responden menjawab bahwa sarana yang digunakan berkualitas, (2) 1 (satu) orang (10\%) responden menjawab sangat berkualitas, dan (3) sebanyak 5 (lima) orang (50\%) responden memberikan jawaban bahwa sarana yang digunakan cukup berkualitas. Dari hasil respon tersebut dapat dikategorikan bahwa kualitas sarana yang digunakan 100\% berkualitas.

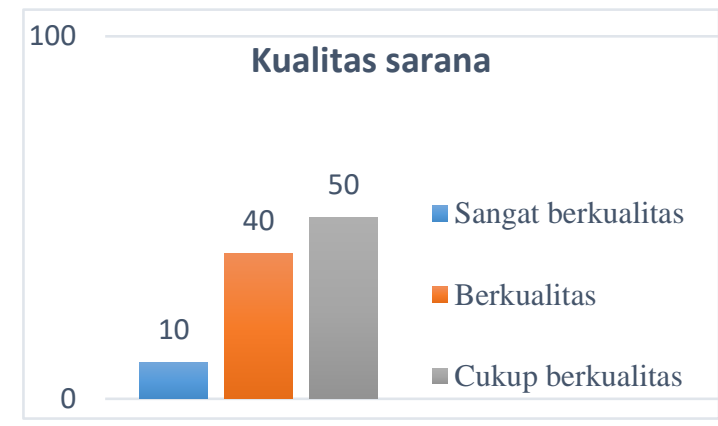

\section{Kelayakan Fasiltas Olahraga Pertandingan}

Berdasarkan hasil yang diperoleh dari jawaban responden, menunjukkan, (1) fasilitas yang digunakan dalam pertanding, 7 (tujuh) orang responden (70\%) memberikan jawaban layak, (2) 1 (satu) orang responden (10\%) manjawab sangat layak, dan (3) sebanyak 2 (dua) orang responden memberikan jawaban cukup layak. Artinya bahwa secara keseluruhan fasilitas olahraga yang digunakan dalam pertandingan menunjukkan $100 \%$ layak.

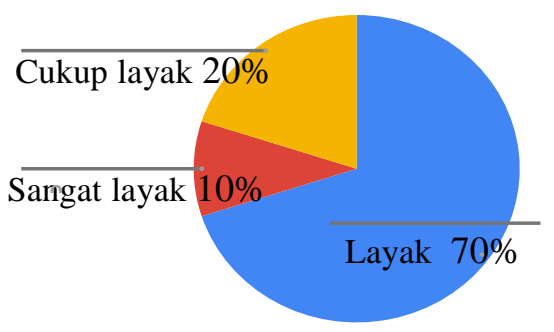

\section{Kualitas Fasiltas Olahraga Pertandingan}

Sedangkan berkaitan dengan kualitas olahraga yang digunakan dalam pertandingan, hasil yang diperoleh adalah sebagai berikut: (1) 5 (lima) orang responden (50\%) menjawab fasilitas olahraga berkualitas dan (2) 5 (lima) orang responden (50\%) memberikan jawaban cukup berkualitas. Jika disimpulkan secara keseluruhan dapat dikatakan bahwa fasilitas olahraga yang digunakan $100 \%$ berkualitas.

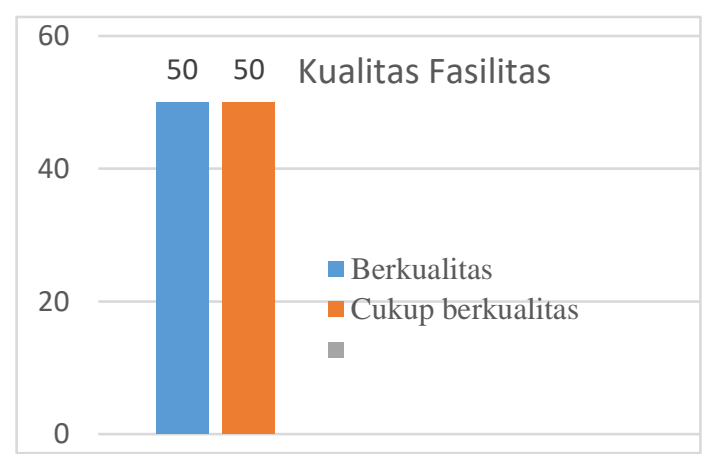


5. Obyektifitas Wasit, Lines Man, Service Judge, dalam Memimpin Pertandingan

Hasil dari jawaban responden menunjukkan, (1) 1 (satu) responden (10\%) menjawab sangat obyektif, (2) 7 (tujuh) orang responden (70\%) memberikan jawaban obyektif, dan 2 (dua) orang responden (20\%) memberikan jawaban cukup obyektif. Dengan demikian dapat dimaknai bahwa secara keseluruhan atau $100 \%$, wasit, lines man, service judge, dsb., dalam memimpin pertandingan dalam kategori obyektif.

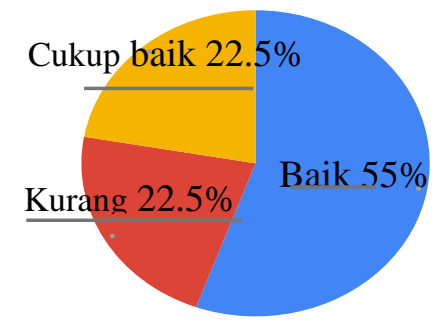

\section{Kinerja Panitia Pertandingan dalam Melaksanakan Tugas}

Berdasarkan hasil survei diperoleh data sebagai berikut. (1) sebanyak 6 (enam) responden menjawab bahwa kinerja panitia dalam kategori baik, (2) sebanyak 2 (dua) orang responden menyatakan kinerja panitia cukup baik, dan (3) sebanyak 2 (dua) responden memberikan jawaban kurang baik. Artinya jika dikategorikan dalam dua kategori baik dan tidak baik, maka sebanyak 8 (delapan) responden menyatakan bahwa kinerja panitia pertandingan dalam kategori baik dan 2 (dua) responden menyatakan bahwa kinerja panitia pertandingan dalam kategori tidak baik.

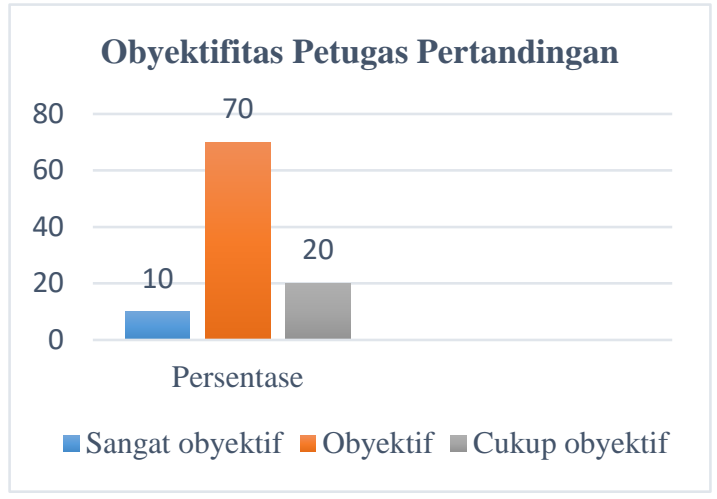

\section{Keramahan Panitia Pertandingan dalam Melaksanakan Tugas}

Berdasarkan hasil survei, diperoleh jawaban dari responden sebagai berikut. (1) sebanyak 3 (tiga) responden atau (30\%) menyatakan bahwa panitia pertandingan memiliki keramahan dalam kategori sangat ramah, (2) sebanyak 3 (tiga) responden atau (30\%) memberikan jawaban panitia pertandingan dalam kategori cukup ramah. Sedangkan sebanyak 4 (empat) responden atau (40\%) memberikan jawaban bahwa panitia pertandingan dalam kategori ramah.

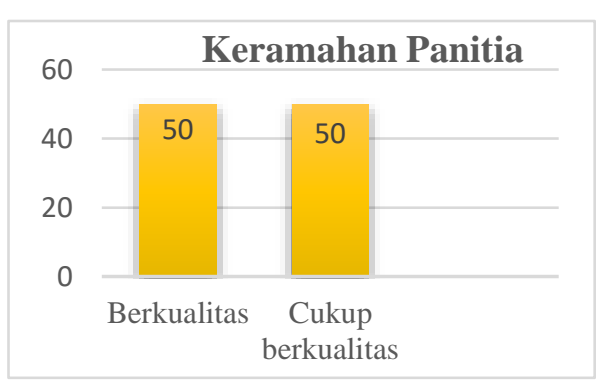

\section{Jumlah Panitia dalam Melaksanakan Tugas Pertandingan \\ Berdasarkan hasil survei kesesuaian jumlah panitia dalam melaksanakan tugas dalam}


pertandingan, diperoleh hasil sebagai berikut. (1) sebanyak 5 (lima) orang responden atau (50\%) menjawab sesuai, (2) sedangkan 1 (satu) orang responden atau $(10 \%)$ memberikan jawaban sangat sesuai, dan sebanyak 4 (empat) orang atau $40 \%$ responden menyatakan cukup sesuai.

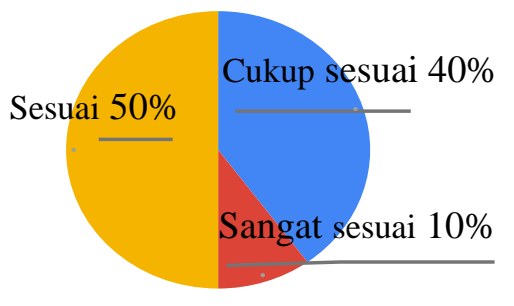

\section{Pelayanan Panitia terhadap Atlet Sebelum dan Selama Pertandingan}

Berdasarkan hasil survei terhadap 10 responden, diperoleh hasil sebagai berikut. (1) sebanyak 1 (satu) orang responden atau (10\%) memberikan jawaban bahwa pelayanan panitia terhadap atlet sebelum dan selama pertandingan sangat sesuai, (2) sedangkan 5 (lima) orang responden atau (50\%) memberikan jawaban pelayanan panitia selama dan sesudah pertandingan sesuai, dan (3) demikian juga sebanyak 4 (empat) orang responden atau $(40 \%)$ memberikan jawaban cukup sesuai.

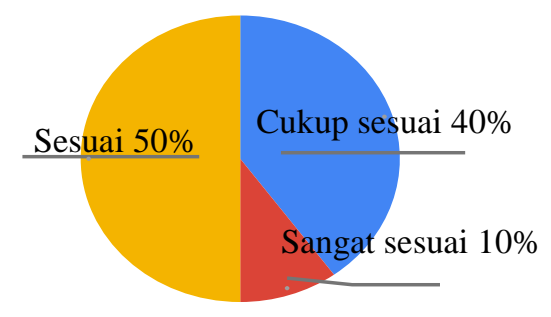

\section{Evaluasi Secara Keseluruhan Pada Cabang Olahraga \\ Berdasarkan hasil survei, ditemukan beberapa jawaban sebagai}

berikut. (1) sebanyak 1 (satu) orang responden atau (10\%) menyatakan bahwa evaluasi secara keseluruhan tugas panitia sangat baik, (2) sebanyak 6 (enam) orang responden atau (60\%) memberikan jawaban panitia bertugas dengan baik, (3) sedangkan sebanyak 3 (tiga) orang responden atau (30\%) menjawab bahwa panitia yang bertugas cukup baik. Artinya jika pilihan ini dikategorikan dalam dua kategori baik dan tidak baik, maka dapat dikatakan bahwa jawaban responden $100 \%$ mengatakan tugas panitia secara keseluruhan baik.

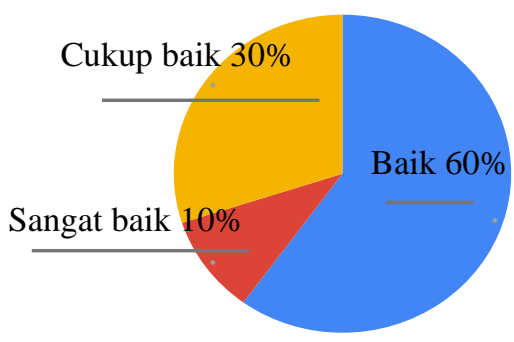

\section{Kebersihan Lingkungan di Sekitar Area Pertandingan}

Berdasarkan hasil survei terhadap 10 orang responden diperoleh hasil sebagai berikut. (1) sebanyak 1 (satu) orang responden atau (10\%) memberikan jawaban bahwa kebersihan lingkungan disekitar area pertandingan sangat bersih, (2) sedangkan sebanyak 6 (enam) orang responden atau (60\%) menjawab bersih, dan (3) sebanyak 2 (dua) orang responden atau (20\%) memberikan jawaban bahwa lingkungan sekitar area pertandingan cukup bersih, (4) demikian juga yang memberikan jawaban kurang bersih sebanyak 1 (satu) orang responden atau (10\%). 


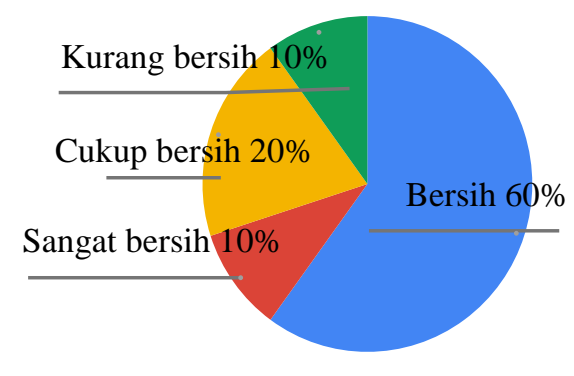

12. Respon Tempat Pertandingan Pertandingan Olahraga di Laksanakan di UM

Berdasarkan hasil survei, diperoleh hasil sebagai berikut. (1) sebanyak 3 (tiga) orang responden atau (30\%) memberikan jawaban terhadap kesan bahwa tempat pertandingan di laksanakan di UM sangat senang, (2) kemudian sebanyak 5 (lima) orang responden atau $(50 \%)$ responden menyatakan senang pertandingan diselenggarakan di UM, dan (3) sebanyak 2 (dua) orang responden menyatakan cukup senang tempat pertandingan di laksanakan di UM.

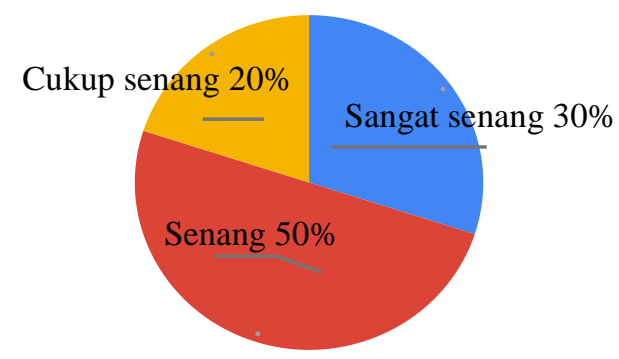

\section{Respon Jika POR HLN Ke 74 Tahun Depan Diselenggarakan Kembali Di UM}

Berdasarkan hasil survei, diperoleh hasil sebagai berikut. (1) sebanyak 3 (tiga) orang responden atau (30\%) menyatakan sangat setuju jika pertandingan di selenggarakan di UM, (2) demikian juga sebanyak 3 (tiga) orang responden atau (30\%) menyatakan setuju jika tahun berikutnya pertandingan diselenggarakan di UM, (3) sedangkan sebanyak 2 (dua) orang responden memberikan jawaban cukup setuju, (4) sebanyak 2 (dua) orang responden atau (20\%) berpendapat tidak setuju. Dari hasil survei ini dapat dikatakan bahwa 8 (delapan) orang responden atau $(80 \%)$ responden setuju jika pertandingan untuk tahun berikutnya diselenggarakan di UM.

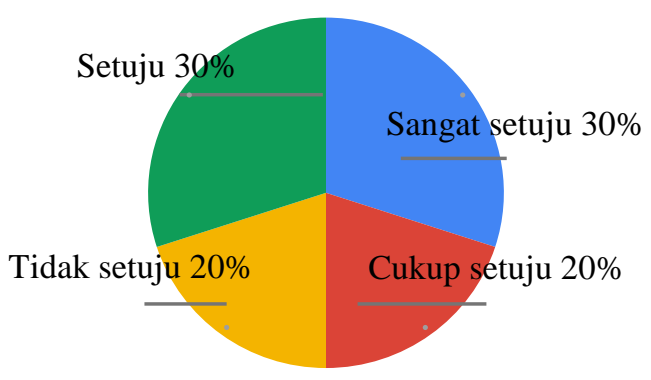

\section{PEMBAHASAN}

Dari hasil respon yang diperoleh dari pertanyan tentang 1) kelengkapan sarana yang digunakan, maka dapat di maknai bahwa sarana yang digunakan dalam penyelenggaraan pertandingan olahraga multievent dalam kategori $90 \%$ lengkap, 2) Dari hasil respon tentang kualitas sarana dapat dikategorikan bahwa sarana yang digunakan 100\% berkualitas, 3) dari aspek kelayakan keseluruhan fasilitas olahraga yang digunakan dalam pertandingan menunjukkan 100\% layak, 4) secara keseluruhan bahwa kualitas fasilitas olahraga yang digunakan 100\% berkualitas, 5) bahwa secara keseluruhan atau 100\%, wasit, lines man, service judge, dsb., dalam memimpin pertandingan dalam kategori obyektif, 6) sebanyak 8 (delapan) responden menyatakan bahwa kinerja 
panitia pertandingan dalam kategaori baik dan 2 (dua) responden menyatakan bahwa kinerja panitia pertandingan dalam kategori tidak baik, 7) dari aspek keramahan panitia diperoleh kategori $100 \%$ ramah, 8) dari aspek kesesuaian jumlah panitia, diperoleh jawaban 100\% sesuai, 9) aspek pelayanan panitia terhadap atlet sebelum dan selama pertandingan diperoleh $100 \%$ sesuai, 10) artinya jika pilihan ini dikategorikan dalam dua kategori baik dan tidak baik, maka dapat dikatakan bahwa jawaban responden $100 \%$ mengatakan tugas panitia secara keseluruhan baik, 11) kebersihan lingkungan pertandingan menurut responden $90 \%$ menjawab baik, 12) kesan yang diberikan responden secara keseluruhan $100 \%$ senang, 13) pertandingan berikutnya tetap dilaksanakan di Malang, $80 \%$ responden menjawab setuju.

Menurut Reftari, D. H., Suryana, A., \& Setiaman, A. (2019) strategi promosi organisasi PB PRSI dalam mempromosikan olahraga renang di Indonesia ialah dengan berbagai macam cara mulai dari media sosial, media cetak, media televisi, serta melalui komunikasi pemasaran terpadu: berupa event. Cara mempromosikannya melalui beberapa konsep dari komunikasi pemasaran serta pemasaran olahraga seperti iklan, public relations, dan personal selling. Demikian juga menurut Reese, J. D., \& Kerr, M. D., (2013) secara individual menilai bagaimana kualitas layanan dan kepuasan pelanggan memengaruhi niat pembelian kembali. Namun, sedikit yang diketahui tentang bagaimana tingkatan harga mempengaruhi persepsi konsumen tentang kualitas acara. Kami mengusulkan di bawah ruang lingkup teori prospek, konsumen dalam tingkatan harga yang berbeda akan mengevaluasi kualitas tempat olahraga secara berbeda. Ini kemudian akan secara langsung mempengaruhi niat pembelian kembali ketika dimoderasi oleh kepuasan pelanggan. Sedangkan Shonk, D. J., \& Chelladural, P., (2008) menyatakan kualitas pariwisata olahraga ditunjukkan oleh empat dimensi utama yang masingmasing ditentukan oleh dua atau lebih subdimensi. Dimensi utama adalah (a) kualitas akses (terdiri dari akses ke tujuan, tempat olahraga, hotel), (b) kualitas akomodasi (termasuk lingkungan, interaksi, dan nilai), (c) kualitas venue (terdiri dari lingkungan, interaksi, dan nilai), dan (d) kualitas kontes (ditunjukkan oleh proses kontes dan produk dari kontes). Model multidimensi yang diusulkan dari kualitas wisata olahraga akan memfasilitasi penelitian ke dalam dinamika pariwisata olahraga dan menawarkan pedoman bagi para praktisi karena mereka terus berupaya untuk memberikan pengalaman terbaik bagi para wisatawan olahraga.

Tujuan dari penelitian ini adalah untuk menguji bagaimana aspek kualitas layanan acara olahraga dioperasionalkan melalui lingkungan fisik, interaksi, dan faktor hasil mempengaruhi kepuasan keseluruhan dengan acara dan kebahagiaan pengalaman. Data dikumpulkan dari 300 pelari yang berpartisipasi dalam balapan $5 \mathrm{k}$ dan 10k. Analisis pemodelan persamaan struktural mengungkapkan efek positif dari hasil dan faktor lingkungan fisik pada kepuasan dengan acara dan pengaruh positif dari kepuasan acara dan kualitas hasil pada kebahagiaan pengalaman. Harapan keseluruhan pada kualitas pengalaman acara dapat menjadi fokus bagi manajer acara yang bertujuan untuk mencapai tujuan pemasaran sosial terkait dengan psikologi positif dari partisipasi acara (Theodorakis, N. D., Kaplanidou, K. (Kiki), \& Karabaxoglou, I., 2015). 
Studi ini memperkirakan efek dari peristiwa dua hari, Rally Ourense, yang terjadi di sebuah kota kecil di Spanyol. Dampak ekonomi diperkirakan berdasarkan survei para penonton dan wawancara para pesaing pada edisi 2009, 2010, dan 2011. Hasil menunjukkan bahwa balapan memiliki efek yang menguntungkan, tetapi juga menunjukkan bahwa dampaknya dapat ditingkatkan dengan beberapa perubahan sederhana pada struktur acara. Tujuan dari penelitian ini adalah untuk menguji bagaimana aspek kualitas layanan acara olahraga dioperasionalkan melalui lingkungan fisik, interaksi, dan faktor hasil mempengaruhi kepuasan keseluruhan dengan acara dan kebahagiaan pengalaman. Data dikumpulkan dari 300 pelari yang berpartisipasi dalam balapan $5 \mathrm{k}$ dan $10 \mathrm{k}$ (Barajas, A., Coates, D., \& Sanchez-Fernandez, P. (2016).

\section{KESIMPULAN}

Dari hasil survei yang diperoleh, menunjukkan masukan-masukan yang lebih bersifat konstruktif, antara lain: (1) pada dasarnya semua pertandingan dapat berlangsung dengan baik dan memuaskan. Hanya terkadang pada saat pertandingan sepakbola di partai final petugas pengambil bola yang keluar lapangan masih kurang. Sehingga pemain harus mengambil sendiri bola yang keluar lapangan, (2) panitia sebaiknya lebih memperhatikan tentang jadwal pertandingan, agar pertandingan dapat berlangsung dengan baik, (3) untuk cabang olahraga basket, responden memberikan masukan sebaiknya dapat diselenggarakan di ruang tertutup (indoor) (4) demikian juga masukan terhadap cabang olahraga bolavoli, terdapat masukan bahwa pertandingan bolavoli akan lebih baik jika pertandingan tahun berikutnya di lapangan tertutup (indoor), (5) berharap agar panitia mempersiapkan jauh-jauh hari dan lebih matang lagi dengan harapan cabang olahraga non vaforit dan atletnya juga lebih melakukan persiapan, serta banyak berkomunikasi dengan BKK di unit masing-masing agar BKK dapat menyiapkan atletnya dengan lebih baik, (6) dan masukan terakhir adalah hendaknya disekitar pertandingan disediakan tempat sampah dan diberi petunjuk arah ke toilet disekitar tempat pertandingan.

\section{DAFTAR PUSTAKA}

Barajas, A., Coates, D., \& Sanchez-Fernandez, P. (2016). Beyond retrospective assessment. Sport event economic impact studies as a management tool for informing event organization. European Research on Management and Business Economics, 22(3), 124130. https://doi.org/10.1016/j.iedee.2015.05.001

Cecep Supriadi Posted on July 23, 2014 https://marketing.co.id/apa-itusport-marketing/

Harsuki, M.A dalam bukunya " Pengantar Manajeman Olahraga “ ; 2012

https://en.wikipedia.org/wiki/Sports_marketing

https://karinov.co.id/pengertian-bauranpemasaran-7p/

Nugroho, A., 2005. Strategi Pemasaran Pada Bisnis Industri Olahraga. Universitas Negeri Yogyakarta.

Philip Kotler, Hermawan Kartajaya, Iwan Setiawan dalam bukunya “Marketing 3,0 "; 2010

Quester, P.G., 2010. Strategic Sport Marketing. Australasian Marketing Journal (AMJ) 6, 95-97. 
doi:10.1016/s1441-

3582(98)70242-3

Reese, J. D., \& Kerr, M. D. (2013). Price tiers as antecedents of event quality in the sport industry. International Journal of Revenue Management, 7(2), 119-137. https://doi.org/10.1504/IJRM.20 13.055684 .

Reftari, D.H., Suryana, A., Setiaman, A., 2019. Komunikasi Pemasaran Olahraga Renang. Jurnal Kajian Komunikasi $6, \quad 247$. doi:10.24198/jkk.v6i2.13221

Schwarz, E. C., Hunter, J. D. (2013). Advanced Theory and Practice in Sport marketing. London: Routledge.

Shonk, D. J., \& Chelladural, P. (2008). Service quality, satisfaction, and intent to return in event sport tourism. Journal of Sport Management, 22(5), 587-602. https://doi.org/10.1123/jsm.22.5. 587
Smith, A.C.T., 2008. Introduction to Sport Marketing, Managing Sport and Leisure. doi:10.1080/23750472.2015.1074 831)

Stewart, B., \& Smith, A. C. (2014). Introduction to sport marketing. Routledge

Theodorakis, N. D., Kaplanidou, K. (Kiki), \& Karabaxoglou, I. (2015). Effect of Event Service Quality and Satisfaction on Happiness Among Runners of a Recurring Sport Event. Leisure Sciences, 37(1), 87-107. https://doi.org/10.1080/0149040 0.2014 .93884

Theodorakis, N. D., Kaplanidou, K. (Kiki), \& Karabaxoglou, I. (2015). Effect of Event Service Quality and Satisfaction on Happiness Among Runners of a Recurring Sport Event. Leisure Sciences, 37(1), 87-107. https://doi.org/10.1080/0149040 0.2014 .938846 